Bangladesh J. Plant Taxon. 27(1): 173-184, 2020 (June)

(C) 2020 Bangladesh Association of Plant Taxonomists

\title{
EVALUATION OF GENETIC DIVERSITY AND MORPHOLOGICAL VARIABILITY IN STELLARIA MEDIA (L.) VILL. USING RAPD MARKER
}

\author{
Shahram Mehri*, Hassan Shirafkan-Ajirlou and Iman Kolbadi \\ Department of Agronomy and Plant Breeding, ParsAbad Moghan Branch, \\ Islamic Azad University, ParsAbad Moghan, Iran
}

Keywords: Gene flow; Morphology; RAPD; Species relationship; Stellaria media.

\begin{abstract}
Stellaria media (L.) Vill., known under the name of chickweed, is an annual medicinal plant in the family Caryophyllaceae. This species is distributed in the north regions of Iran. In the present study, the Random Amplified Polymorphic DNA (RAPD) technique was used to estimate infraspecific variation in different populations of Stellaria media. Samples from 11 populations were collected from different regions of the country during spring 2018. For RAPD investigations, populations were divided into three geographical regions. This study provides important data on the genetic diversity, population structure and morphological characteristics of Stellaria media. The AMOVA and Gst analyses showed that the populations of this species are genetically differentiated. $\mathrm{Nm}$ analysis revealed very low value of genetic diversity among the studied population and mantel test indicated isolation by distance occurred among them. The studied populations of $S$. media are differentiated in morphological characteristics and genetic content.
\end{abstract}

\section{Introduction}

Genetic diversity, one of the basic levels of biodiversity, determines the evolutionary potential of a taxon or population to adapt to variable environmental conditions (Morton, 2005). Genetic diversity arises from different factors such as mutation or gene flow, while events, for example, genetic drift and directional selection, can decrease the diversity. The family Caryophyllaceae comprised of about 81 genera and 2600 species (Bittrich, 1993; Ullah et al., 2019; EsfandaniBozchaloyi et al., 2017a,b,c,d; 2018a,b,c; Esfandani -Bozchaloyi and Sheidai 2018). Stellaria L. (Caryophyllaceae, Alsinoideae) includes both annual and perennial herbaceous plants that are widely distributed in the temperate zones of Europe and Asia (Lu and Rabeler, 2001; Keshavarzi and Esfandani-Bozchaloyi, 2014a, b; Ullah et al., 2019) and about 120 species with worldwide distribution, mainly in the north temperate zone (Morton, 2005; Ullah et al., 2018). In Flora Iranica, this genus has nine species under two sections: sect. Pseudalsine Boiss. consists of one species $S$. alsinoides Boiss. \& Buhse and sect. Stellaria of six species viz., S. holostea L., S. persica Boiss., S. graminea L., S. nemorum L., S. media (L.) Vill., and S. pallida (Dumort.) Pire (Rechinger, 1988). The main center of diversification for Stellaria is Eurasia, with a center of distribution in the mountains of central Asia. Some species are also cosmopolitan (Bittrich, 1993; Ullah et al., 2018).

There are limited chromosome records for Stellaria in the world. Basic chromosome numbers of $\mathrm{x}=10,11,12$ and 13 have been reported for the genus (Federov, 1969 1974; Moore, 1973; Goldblatt, 1981). Stellaria media, known as chickweed, are annual and with slender stems, they have hairs on one side of the stem. The leaves are linear or oval, smooth or minutely, 13 to $17 \times$

*Corresponding author, email: sh.mehri2000@gmail.com 
1.5 to $7 \mathrm{~mm}$. Flowers are hermaphrodite. Sepals prominently 4 to 6 -nerved. The number of stigmas and stamens are 3 each. S. media is common in waste places, open areas, lawns, meadows, and widely distributed to temperate regions of Europe, Asia and Northern America. S. pallida is distributed in the all regions of Iran. This plant is edible and nutritious and considered to be a herbal remedy and useful in folk medicine. S. pallida is very similar to S. media. Stellaria media has some medicinal properties. This species has been used as to soothe severe itchiness even where all other remedies have failed (Slavokhotova et al., 2011). It is considered for rheumatic pains, skin diseases, and period pain as well as for bronchitis and arthritis (Slavokhotova et al., 2011). Rani et al. (2012) have studied some stem and leaf anatomical features through the pharmacognostical study for quality control of S. media. Arora and Sharma (2012) did pharmacognostical and phytochemical studies of $S$. media and showed the presence of epidermis, palisade cells, trichomes and vascular bundles in leaf. S. media possesses significant chemicals known as saponins, which can cause poisoning in cattle (Haragan, 1991). Many studies have been done on taxonomy, pollen morphology, phylogeny, seed micromorphology, anatomy, trichome and cytology of Stellaria species (Esfandani-Bozchaloyi and Keshavarzi, 2014; Keshavarzi and Esfandani-Bozchaloyi, 2014 a, b; Ullah et al. 2018). However, genetic diversity of Stellaria species have been reported only in a few studies (Verkleij et al., 1980; Chinnappa and Morton, 1984), and outcrossing or inbreeding, genetic structure, genetic variability within/between populations and ecological adaptation in Stellaria of Iran have not been investigated yet.

The molecular markers are extensively used in germplasm characterization, fingerprinting, genetic analysis, linkage mapping, and molecular breeding. RAPD (Random Amplified Polymorphic DNA) analysis using PCR in association with short primers of arbitrary sequence has been demonstrated to be sensitive in detecting variation among individuals. The advantages of this technique are: a) a large number of samples can be quickly and economically analyzed using only micro-quantities of material; b) the DNA amplicons are independent from the ontogenetic expression; and c) many genomic regions can be sampled with a potentially unlimited number of markers (Ellis and Burke, 2007; Esfandani-Bozchaloyi et al., 2017a,b,c,d). The present investigation has been carried out to evaluate the genetic diversity and relationships among 11 geographical populations of $S$. media using RAPD markers. This is the first study on the use of RAPD markers in S. media; Therefore, we performed molecular study of 110 collected specimens of 11 geographical populations.

\section{Materials and Methods}

\section{Morphological studies}

110 plant sample were selected from eleven populations located in three provinces of Iran. Identification of $S$. media species were based on the descriptions provided by Flora Iranica (Rechinger, 1988). The sampling sites are provided in Table 1 and Fig. 1. Voucher specimens were deposited at the herbarium of Islamic Azad University, Science and Research Branch, Tehran, Iran (IAUH).

\section{DNA extraction}

Fresh leaves were used randomly from one to twelve plants in each of the studied populations. These were dried by silica gel powder. CTAB activated charcoal protocol was used to extract genomic DNA (Esfandani-Bozchaloyi et al., 2018a,b,c). The quality of extracted DNA was examined by running on $0.8 \%$ agarose gel. 25 decamer RAPD primers of Operon technology (Alameda, Canada) belonging to OPA, OPB, OPC, OPD sets were used in this study. 10 primers with clear, enlarged, and rich polymorphism bands were chosen. PCR were carried out in $25 \mu 1$ 
reactions containing $20 \mathrm{ng}$ of template DNA, $0.3 \mathrm{mM}$ dNTPs, $1 \mu \mathrm{M}$ primers, $1.0 \mu \mathrm{l}$ of $20 \times \mathrm{PCR}$ buffer (Cinnagen, Iran), $1.8 \mathrm{mM}$ of $\mathrm{MgCl}_{2}$ and 5 units of Taq polymerase (Cinnagen, Iran).

Table 1. Location addresses and ecological characters of the Stellaria media

\begin{tabular}{llllll}
\hline $\begin{array}{l}\text { Popu- } \\
\text { lation }\end{array}$ & Locality & Latitude & Longitude & $\begin{array}{l}\text { Altitude } \\
(\mathrm{m})\end{array}$ & Voucher no. \\
\hline 1 & Guilan, Road to Sangar & $37^{\circ} 06^{\prime} 57^{\prime \prime \prime}$ & $49^{\circ} 11^{\prime} 06^{\prime \prime}$ & 47 & IAUH 201600 \\
\hline 2 & $\begin{array}{l}\text { Guilan, Bandar Anzali, Pine artificial } \\
\text { woodland }\end{array}$ & $37^{\circ} 27^{\prime} 34^{\prime \prime}$ & $49^{\circ} 42^{\prime} 40^{\prime \prime}$ & -25 & IAUH 201701 \\
& & & & \\
\hline 3 & Guilan, Loleman & $37^{\circ} 28^{\prime} 59^{\prime \prime}$ & $49^{\circ} 33^{\prime} 45^{\prime \prime}$ & -29 & IAUH 201702 \\
\hline 4 & Guilan, Siahkal, Sangar & $37^{\circ} 09^{\prime} 08^{\prime \prime}$ & $49^{\circ} 55^{\prime} 02$ & 27 & IAUH 201603 \\
\hline 5 & Golestan, Golerodbar river & $37^{\circ} 10^{\prime} 05^{\prime \prime}$ & $49^{\circ} 56^{\prime} 38^{\prime \prime}$ & 15 & IAUH 201604 \\
\hline 6 & Guilan, Sheytankouh hill side & $37^{\circ} 12^{\prime} 04^{\prime \prime}$ & $50^{\circ} 03^{\prime} 12^{\prime \prime}$ & 9 & IAUH 201605 \\
\hline 7 & Guilan, Lahijan, Highlands of Sheytan & $37^{\circ} 11^{\prime} 52^{\prime \prime}$ & $50^{\circ} 03^{\prime} 17^{\prime \prime}$ & 159 & IAUH 201606 \\
\hline 8 & Kouh & & & & \\
\hline 9 & Guilan, Bandar Anzali, Road side & $37^{\circ} 27^{\prime} 48^{\prime \prime}$ & $49^{\circ} 22^{\prime} 30^{\prime \prime}$ & -11 & IAUH 201707 \\
\hline 10 & Mazandaran, ChalosNeamatabad & $36^{\circ} 49^{\prime} 02^{\prime \prime}$ & $50^{\circ} 52^{\prime} 20^{\prime \prime}$ & -16 & IAUH 201608 \\
\hline 11 & Mazandaran, Shirodi Ring Road & $36^{\circ} 51^{\prime} 10^{\prime \prime}$ & $50^{\circ} 32^{\prime} 11^{\prime \prime}$ & -18 & IAUH 201709 \\
\hline
\end{tabular}

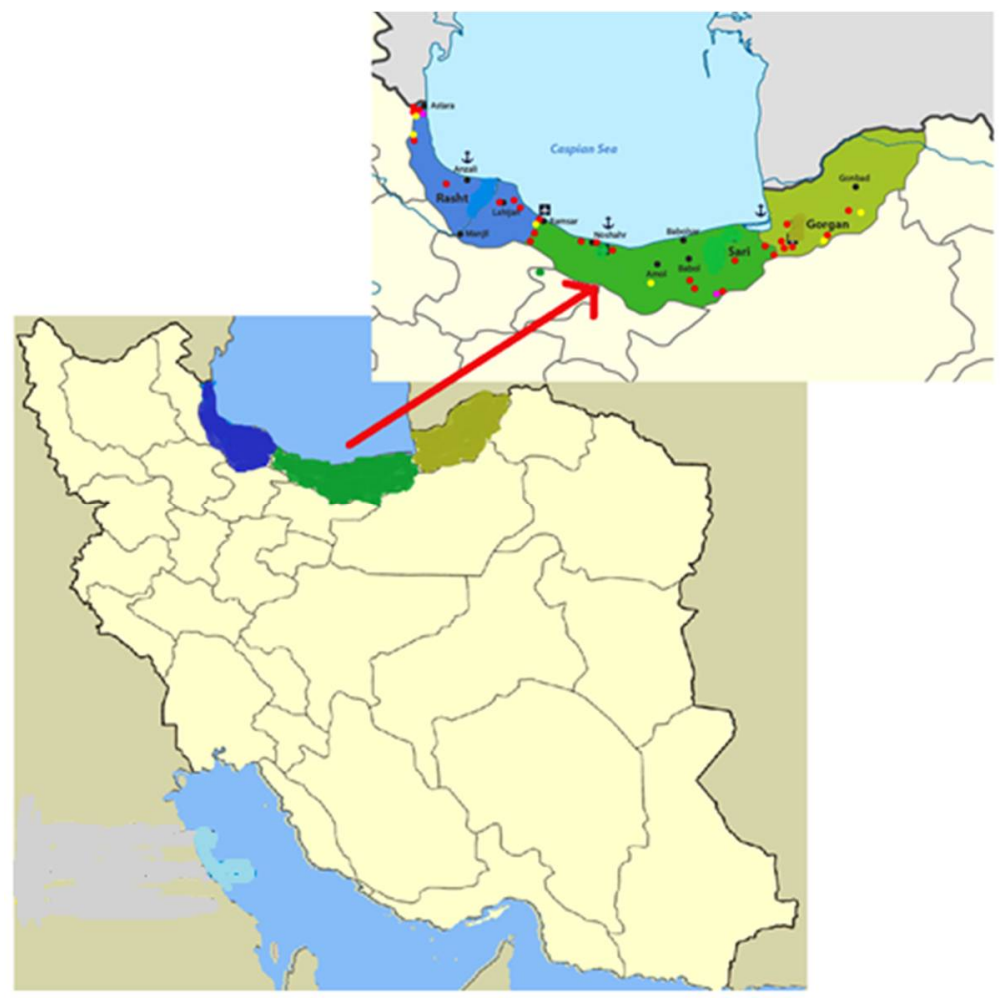

Fig. 1. Distribution map of the studied populations. 
The amplification was carried out, with programmed as initial pre-denaturation at $95^{\circ} \mathrm{C}$ for 5 min followed by 36 cycles of denaturation at $94^{\circ} \mathrm{C}$ for $45 \mathrm{~s}$, annealing at temperature $\left(52-55^{\circ} \mathrm{C}\right)$ for $40 \mathrm{~s}$, and extension at $72^{\circ} \mathrm{C}$ for $1 \mathrm{~min}$. A final $5 \mathrm{~min}$. extension at $72^{\circ} \mathrm{C}$ followed the completion of 38 cycles.

\section{Data analyses}

Morphological studies

For morphological studies, 43 morphological characters including 16 qualitative and 26 quantitative characters were studied following Attar et al. (2019, Table 2).

\section{Table 2. List of selected characters and their codes in morphological studies.}

\begin{tabular}{|c|c|c|}
\hline No. & Characters & Numerical code \\
\hline 1 & Plant height & $\mathrm{mm}$ \\
\hline 2 & Length of basal leaves & $\mathrm{mm}$ \\
\hline 3 & Width of basal leaves & $\mathrm{mm}$ \\
\hline 4 & Length of stem leaves & $\mathrm{mm}$ \\
\hline 5 & Width of stem leaves & $\mathrm{mm}$ \\
\hline 6 & Bract length & $\mathrm{mm}$ \\
\hline 7 & Width bract & $\mathrm{mm}$ \\
\hline 8 & Length pedicel & $\mathrm{mm}$ \\
\hline 9 & Number of seeds per capsule & \\
\hline 10 & $\begin{array}{l}\text { Number of flowers per } \\
\text { inflorescence }\end{array}$ & \\
\hline 11 & Number of calyx & \\
\hline 12 & Length calyx & $\mathrm{mm}$ \\
\hline 13 & Width calyx & $\mathrm{mm}$ \\
\hline 14 & Number of petal & \\
\hline 15 & petal length & $\mathrm{mm}$ \\
\hline 16 & Petal width & $\mathrm{mm}$ \\
\hline 17 & Cleft size of petals & $\mathrm{mm}$ \\
\hline 18 & Inter node length & $\mathrm{mm}$ \\
\hline 19 & Number of stamen & \\
\hline 20 & Number of stigma & \\
\hline 21 & Capsule length & $\mathrm{mm}$ \\
\hline 22 & Seed length & $\mathrm{mm}$ \\
\hline 23 & Seed width & $\mathrm{mm}$ \\
\hline 24 & Cleft size of capsule & $\mathrm{mm}$ \\
\hline 25 & Number suture capsules & \\
\hline 26 & Veins number sepals & \\
\hline
\end{tabular}




\begin{tabular}{lll}
\hline 27 & Growth period & 0-annual 1- perennial \\
\hline 28 & Bract apex & 0-acute 1- narrow 2-absence \\
\hline 29 & State of stem & 0-unbranched 1- branched \\
\hline 30 & State of stem strength & 0-thin 1- strong \\
\hline 31 & Hairs of stem & 1-unilateral hair 2- multilateral hair \\
\hline 32 & Cross-section of stem & 0-round1- rectangular 2- elliptical \\
\hline 33 & Shape of basal leaves & 0-linear 1- linear- lanceolate \\
\hline 34 & Basal leaves apex & 0-acute 1- narrow \\
\hline 35 & Basal leaves petiole & 0-absence 1- presence \\
\hline 36 & Hair of basal leaves petiole & 0-absence 1- presence \\
\hline 37 & Shape caulin leaves & 0- linear 1- linear- lanceolate \\
\hline 38 & Caulin leaves apex & 0-acute 1- narrow \\
\hline 39 & Caulin leaves petiole & 0-absence 1- presence \\
\hline 40 & Hair of caulin leaves petiole & 0-absence 1- presence \\
\hline 41 & Hair of caulin leaves margin & 0-absence 1- presence \\
\hline 42 & Hair of caulin leaves lamina & 0-absence 1- presence \\
\hline 43 & Shape of bract & 0-linear 1- linear- lanceolate \\
\hline & & \\
\hline
\end{tabular}

Morphological traits were standardized (Mean $=0$, Variance $=1$ ) and used to estimate Euclidean distance for ordination analyses (Podani, 2000). PCA (Principal Components Analysis) biplot and MDS (Multidimensional Scaling) were applied for grouping and identifying the most variable morphological traits among the populations (Podani, 2000). We used PAST version 2.17 (Hammer et al., 2012) for multivariate statistical analyses.

\section{Molecular analyses}

RAPD bands scored as present (1) or absent (0). Genetic polymorphism was determined by genetic diversity parameters: Shannon information index (I), percentage of polymorphism, the number of effective alleles and Nei's gene diversity (H) (Freeland et al., 2011). Neighbor-Net networking was used for Nei's genetic identity among studied populations (Huson and Bryant, 2006; Weising et al., 2005). We used PAST ver. 2.17 (Hammer et al., 2012), SplitsTree4 V4.13.1 ,2013 and DARwin ver. 5, 2012 softwares for data analysis.

For AMOVA (Analysis of molecular variance), we used GenAlex 6.4 software (Peakall and Smouse 2006; Meirmans and Van Tienderen, 2004) to determine the genetic differentiation of the species and Nei'sGst analysis in GenoDive ver.2 (2013) (Hedrick, 2005; Jost, 2008) were used to reveal genetic distance of the species. First data were scored as dominant markers so we used from STRUCTURE analysis for estimation of the parameters that is related to gene flow among studied population. Burn-in $=10000$, and 10 runs were performed for estimation of the relationship between the genetic structures and geographical distance. Maximum likelihood method and Bayesian Information Criterion (BIC) was studied by structure analysis (Falush and Stephens 2007; Evanno et al., 2005; Meirmans, 2012). Gene flow was determined by calculating Nm from Gst by PopGene ver. 1.32, 1997 (Pritchard et al., 2000). 


\section{RESULTS AND DISCUSSION}

In this study 11 populations of Stellaria media were selected from northern regions of Iran. Genetic diversity parameters revealed that the highest percent of genetic polymorphism (70\%) and gene diversity (0.203) exist in Mazandaran, Chalos Neamat abad (population No.9), while the lowest amount of genetic polymorphism (22\%) showed in population in Mazandaran, Noshahr (Table 3).

Table 3. Genetic diversity parameters in the studied populations. $(\mathrm{N}=$ number of samples, $\mathrm{Ne}=$ number of effective alleles, I= Shannon's information index, He = gene diversity, UHe = unbiased gene diversity, $\mathrm{P} \%=$ percentage of polymorphism, populations).

\begin{tabular}{lccccccc}
\hline Pop & $\mathrm{N}$ & $\mathrm{Na}$ & $\mathrm{Ne}$ & $\mathrm{I}$ & $\mathrm{He}$ & $\mathrm{UHe}$ & $\% \mathrm{P}$ \\
\hline pop1 & 5.000 & 0.839 & 1.134 & 0.128 & 0.083 & 0.092 & $25.81 \%$ \\
pop2 & 5.000 & 1.258 & 1.279 & 0.248 & 0.164 & 0.182 & $48.39 \%$ \\
pop3 & 5.000 & 1.097 & 1.220 & 0.214 & 0.137 & 0.153 & $45.16 \%$ \\
pop4 & 5.000 & 1.516 & 1.406 & 0.355 & 0.236 & 0.263 & $67.74 \%$ \\
pop5 & 5.000 & 1.323 & 1.230 & 0.220 & 0.143 & 0.158 & $45.16 \%$ \\
pop6 & 5.000 & 1.516 & 1.411 & 0.353 & 0.238 & 0.264 & $64.52 \%$ \\
pop7 & 5.000 & 1.194 & 1.248 & 0.254 & 0.161 & 0.179 & $54.84 \%$ \\
pop8 & 5.000 & 1.226 & 1.258 & 0.257 & 0.162 & 0.180 & $58.06 \%$ \\
pop9 & 5.000 & 1.452 & 1.318 & 0.320 & 0.203 & 0.226 & $70.97 \%$ \\
pop10 & 5.000 & 0.968 & 1.085 & 0.115 & 0.066 & 0.073 & $32.26 \%$ \\
pop11 & 5.000 & 0.645 & 1.092 & 0.101 & 0.063 & 0.070 & $22.58 \%$ \\
\hline
\end{tabular}

AMOVA test showed that, $35 \%$ of total genetic diversity was within population and $65 \%$ was among population. Hedrick standardized fixation index makes the genetic distance among the studied populations. We have moderate level for AMOVA produced after 999 permutations (G'st $=0.632, \mathrm{P}=0.001)$ and Hedrick differentiation index (D-est $=0.271, \mathrm{P}=0.001)$. Our results showed that the populations of $S$. media are differentiated from each other.

\section{Populations' genetic affinity}

Neighbor-Net network and $\mathrm{Nj}$ tree revealed identitical results but here only Neighbor-Net network is discussed (Fig. 2). This network shows that the populations 3 and 7, as well as populations 4 and 11 are placed close to each other, which indicate that they have closer genetic affinity. The populations 2 and 6 and 8 are differentiated from the other populations. The studied specimen in PCoA plot revealed that they belong to different groups, which is in agreement with the AMOVA results (Fig. 3). The relationship between altitude distance and genetic distance indicated by Mantel test after 5000 permutations is significant in these populations $(r=0.22, \mathrm{P}=0.001)$. The isolation in $S$. media occurred because of low amount of gene flow due to geographically more distant of populations.

\section{Populations genetic structure}

The result carried out on STRUCTURE analyses by Evanno test makes a peak at $\mathrm{k}=6$ (Fig. 4).

Furthermore, STRUCTURE analyses show genetic identity between populations 3 and 4 
(similarly colored), populations 5 and 6 , like populations 10 and 11 . But it indicated genetic difference between populations 1 and 2 (differently colored).

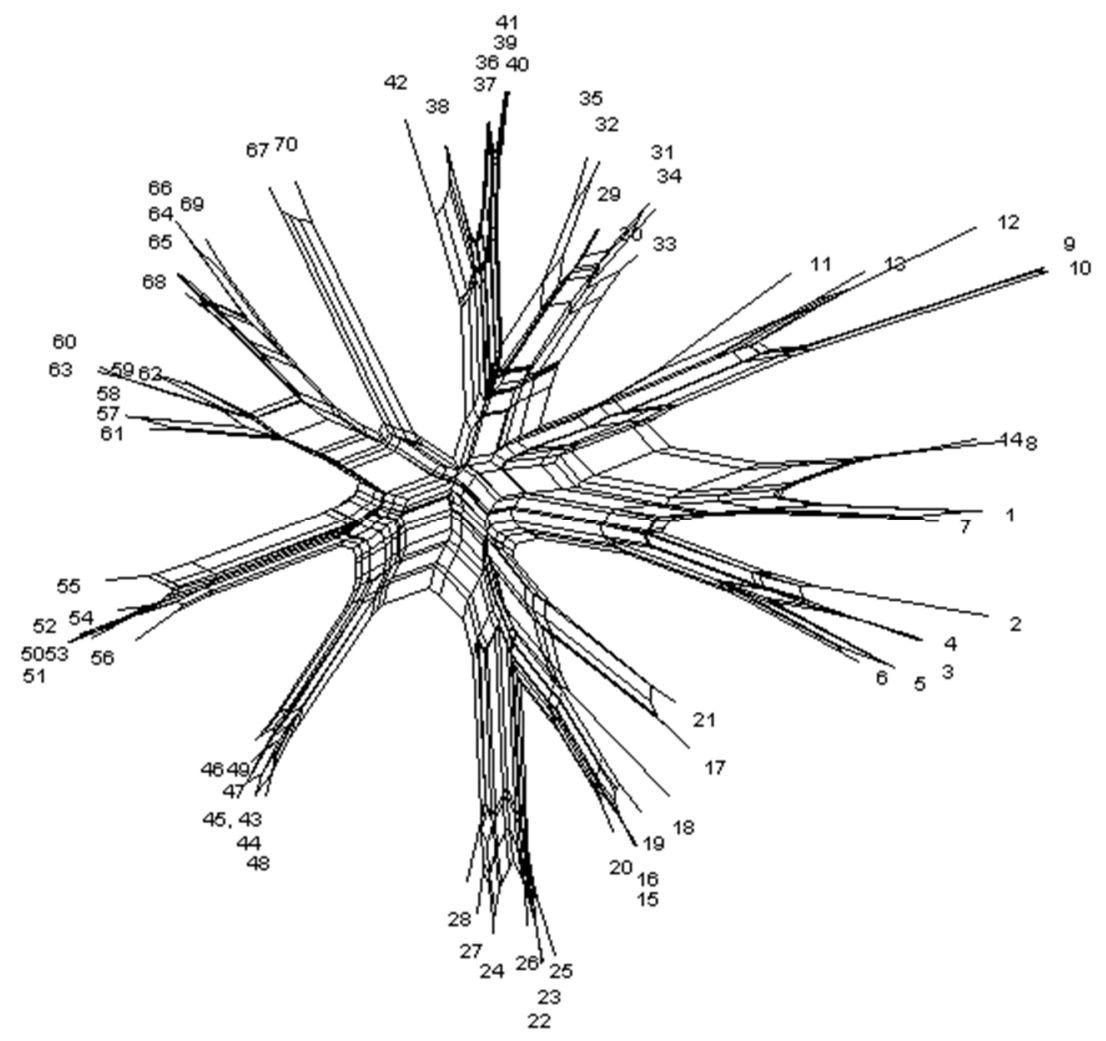

Fig. 2. Neighbor-Net network of populations in S. media based on RAPD data.

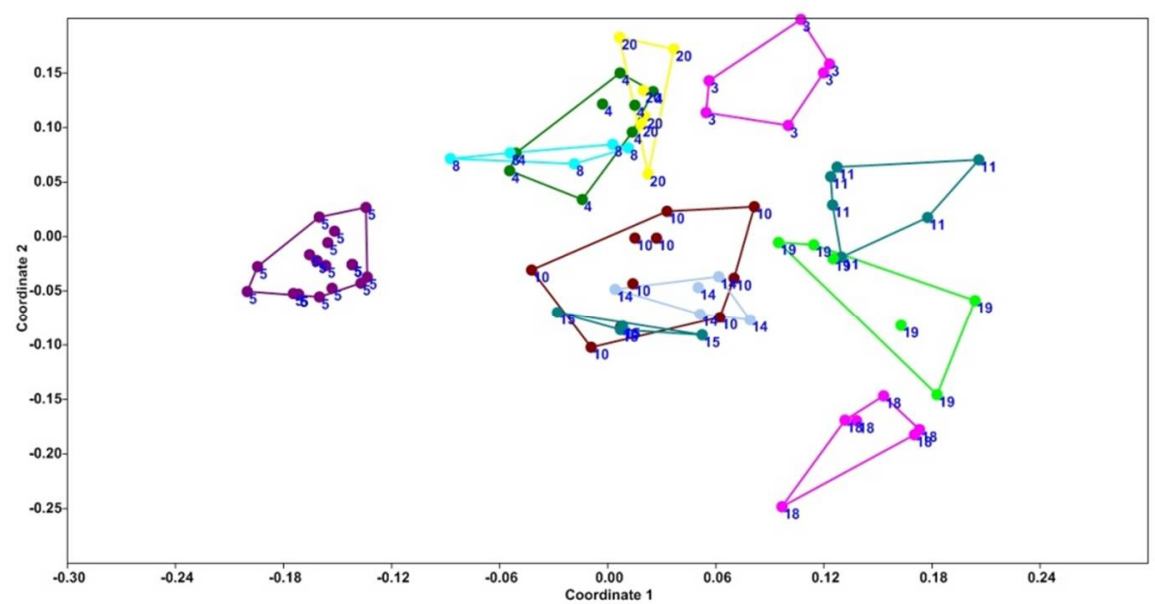

Fig. 3. PCoA plot of populations in S. media based on RAPD data. 


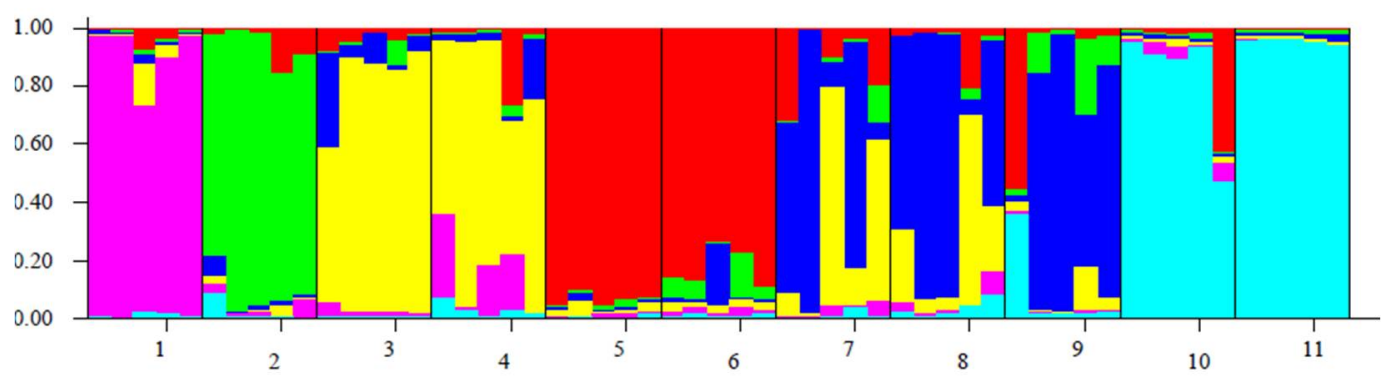

Fig. 4. STRUCTURE plot of $S$. media populations based on $\mathrm{k}=6$ of RAPD data.

The results of Reticulogram (Fig. 5), that is based on the least square method, indicates some of shared alleles among populations 3 and 5, 6 and between 8 and 2 and 11, also between 1, 4, 3 and 9 and 10. The mean $\mathrm{Nm}=0.32$ indicates very low level of genetic diversity and supports genetic stratification as showed by STRUCTURE analyses and K-Means. Nm result agreed with population assignment test and cannot showed gene flow among these populations. In total, ten ISSR primers produced 90 bands, fragment size ranged from 150 to $3000 \mathrm{bp}$.

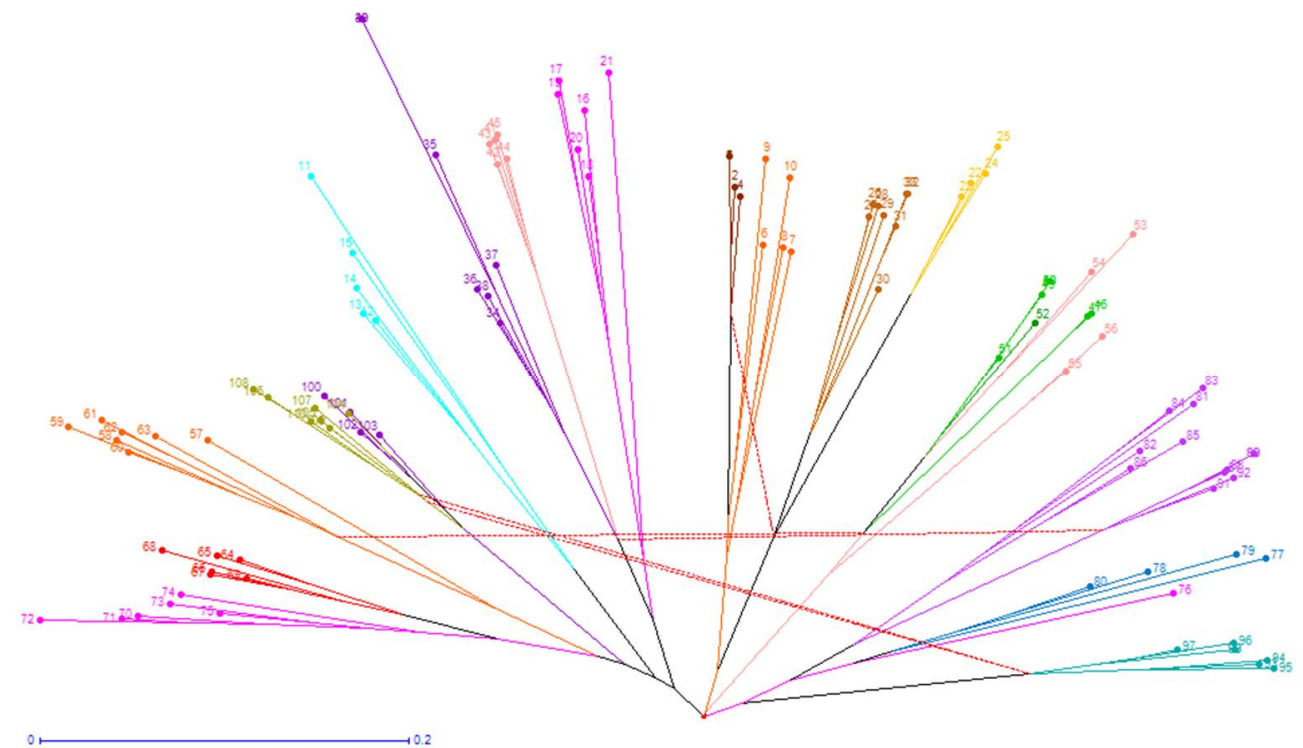

Fig. 5. Reticulogram of $S$. media populations based on least square method analysis of RAPD data (Population numbers are according to Table 1).

\section{Morphometric analyses}

ANOVA tests for 110 plant specimens from 11 populations were performed. Our results indicated significant difference in comparison with the studied populations $(\mathrm{P}<0.05)$. Ordination plot and other analyses produced similar results on these populations (Fig. 6). Our result revealed that among of the studied populations, morphological divergence exist and this divergence was due to quantitative traits. For example, length of stem leaves character separated population No. 2, 
but the populations 4 and 8 separated from the other populations due to difference in calyx length. We performed for both morphological and RAPD data-based a consensus tree (Fig. 7). It indicates that some populations are different from other populations due to both morphological and molecular characters.

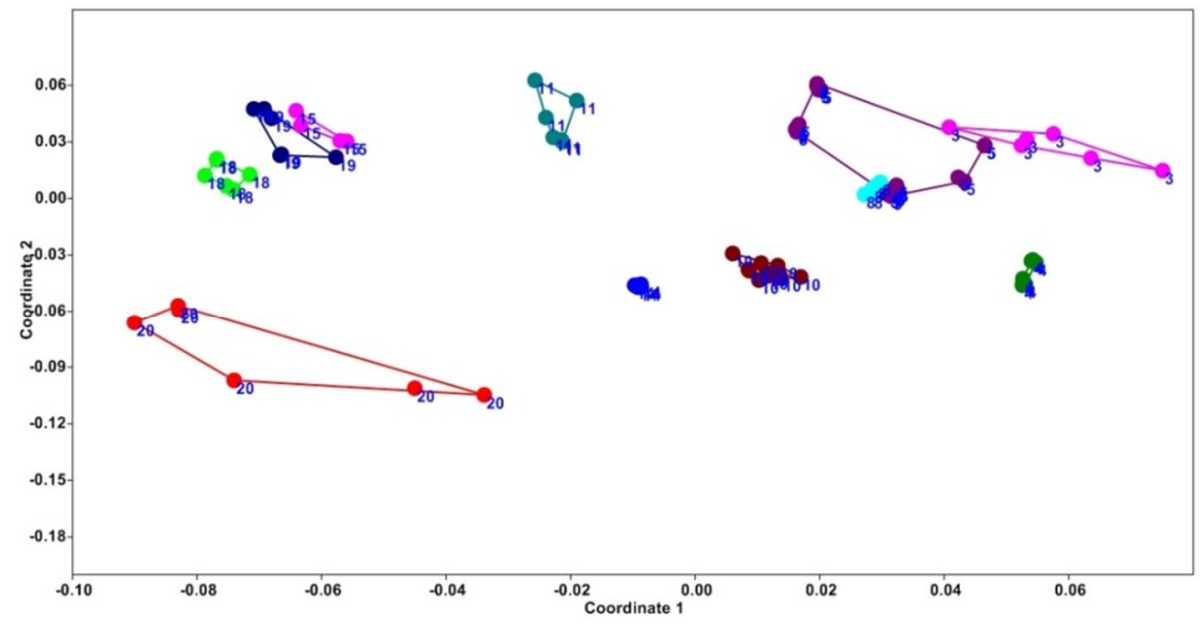

Fig. 6. PCoA plot of S. media populations based on morphological characters.

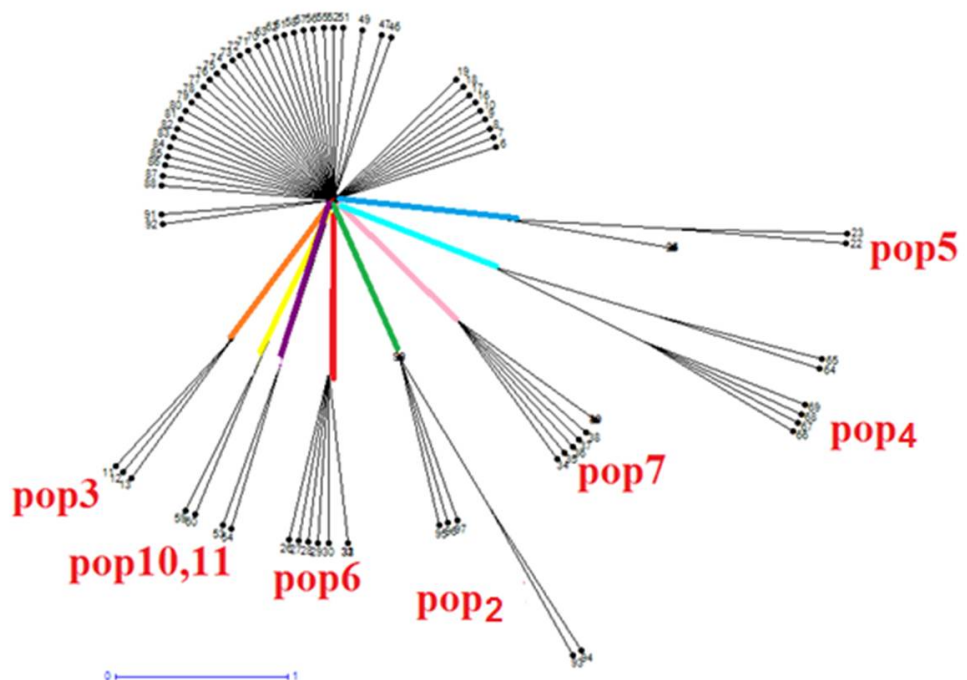

Fig. 7. Consensus tree of morphological and molecular data in S. media populations.

According to Çalişkan (2012) genetic diversity provides information about adaptation to changing environments, understanding of positive influence in the conservation of endangered species, hybridization and gene flow among the populations. This study evaluates the use of RAPD markers for comparing the gene flow and relationships within the population of $S$. media in Iran. Verkleij et al. (1980) showed that Amylases isoenzymes could be successfully applied to assess inter-populational variation in S. media. 
In this study, we have provided information on current taxonomic, molecular and geographical distance and data about gene flow and genetic structure of S. media in some parts of Iran. Chickweed can germinate and flower any time of the year. It is mainly self-pollinating, but sometimes cross-pollination occurs by flies and insects.

According to Chater and Heywood (1993) $S$,. media is a widespread weedy species. There are three subspecies viz., S. media subsp. media, S. media subsp. cupaniana and S. media subsp. postii but some authors showed that subsp. cupaniana (Scholte, 1978) and subsp. postii (Sinha, 1965) should be included in $S$. neglecta. According to Fedorov (1969) chromosome numbers that have been reported for $S$. media included $2 n=24,28,36,38,40,42$ and 44 from many parts of the world. However, chromosome numbers $2 n=40,42$ and 44 are the most commonly reported and this species shows a high degree of genotypic variation that is highly correlated with its reproductive characters (Freeland et al., 2011).

S. media is annual, characterized by the presence of five sepals and petals which are usually bifid. Generally, within family Caryophyllaceae diversity of morphological features makes taxa complicated to be delineated and identified. S. media is occur on abandoned fields and commonly sensitive to disturbance of its habitat. S. pallida and $S$. media are self-pollinating and there are crossing barrier between them. This happened due to the presence of polyploidy in S. media $(2 n=$ 40-44), in contrast to the diploidy of $S$. pallida $(2 n=22)$ (Scholte, 1978; Slatkin, 1993; Jolivet and Bernasconi, 2007). Therefore, breeding systems plays important role in low level of gene flow in S. media (Hutchison and Templeton, 1999; Medrano and Herrera, 2008).

Our results shows that the seed morphologies of Stellaria media and S. pallida are similar. Seed coat cellsare rounded polygonal and V-shaped margin. Based on these characters, we decided that S. media could be differenced from S. pallida. Seed coat morphology was observed in 18 species of Stellaria by Chen (2010).

\section{Conflict of interests}

The authors have not declared any conflict of interest.

\section{References}

Arora, D. and Sharma, A. 2012. Pharmacognostic and Phytochemical Studies of Stellaria media Linn. Journal of Pharmcological sciences and researches 4(5): 1819-1822.

Attar, F., Esfandani-Bozchaloyi, S., Mirtadzadini, M., Ullah, F. and Zaman, W. 2019. Foliar and stem epidermal anatomy of the tribe Cynoglosseae (Boraginaceae) and their taxonomic significance. Microsc Res Tech. 82: 786-802.

Bittrich, V.1993. Caryophyllaceae. in kubitzki, K. Rohwer, J. \& Bittrich, V. (eds.) The families and genera of vascular plant. Vol. 2, Magnoliid, Hamamelid and caryophyllid families. Springer, Berlin, pp. 112: 206236.

Çalişkan, M. 2012. Genetic diversity in plants. InTech. Chapters published under CC BY 3.0 license.110: 33 39.

Chater, A.O. and Heywood, V.H. 1993. Stellaria. In: Tutin, T.G., Burges, N.A., Chater, A.O., Edmondson, J.R., Moore, D.M., Valentine, D.H., Walters, S.M. \& Webb, D.A. (eds), Flora Europaea (ed. 2), Cambridge University Press: Cambridge 1:161-164.

Chen, X.B., Yu, M. and Liu, Q.R. 2010. Micromorphological characteristics and systematical significance of seed coat of StellariaL. from northern China. Journal of Beijing Normal University, Natural Science 46(1): 56-62.

Chinnappa, C.C. and Morton, J.K. 1984.Studies on the Stellaria longipes Complex (Caryophyllaceae). Systematic Botany. 9(1): 60-73. 
Ellis, J.R. and Burke, J.M. 2007. EST-SSRs as a resource for population genetic analyses. Heredity. 99: $125-132$.

Esfandani-Bozchaloyi, S. and Keshavarzi, M. 2014. Micro- and macromorphological study of Stellaria (Caryophyllaceae) and its closest relatives in Iran. PhytologiaBalcanica, 20(2): 179-197.

Esfandani-Bozchaloyi, S., Sheidai, M., Keshavarzi, M. and Noormohammadi, Z. 2017a. Genetic Diversity and Morphological Variability In Geranium Purpureum Vill. (Geraniaceae) Of Iran. Genetika 49: 543557.

Esfandani-Bozchaloyi, S., Sheidai, M., Keshavarzi, M. and Noormohammadi, Z. 2017b. Species Delimitation in Geranium Sect. Batrachioidea: Morphological and Molecular. Act Bot Hung 59: 319-334.

Esfandani-Bozchaloyi, S., Sheidai, M., Keshavarzi, M. and Noormohammadi, Z. 2017c. Genetic and morphological diversity in Geranium dissectum (Sec. Dissecta, Geraniaceae) populations. Biologia 72: 1121-1130.

Esfandani-Bozchaloyi, S., Sheidai, M., Keshavarzi, M. and Noormohammadi, Z. 2017d. Analysis of genetic diversity in Geranium robertianum by ISSR markers. Phytologia Balcanica 23: 157-167.

Evanno, G., S. Regnaut, and Goudet, J. 2005. Detecting the number of clusters of individuals using the software STRUCTURE: a simulation study. Mol. Ecol. 14: 2611-2620.

Esfandani-Bozchaloyi, S., Sheidai, M., Keshavarzi, M. and Noormohammadi, Z. 2018a. Species Relationship and Population Structure Analysis In Geranium Subg. Robertium (Picard) RouyWith The Use of ISSR Molecular Markers. Act Bot Hung, 60: 47-65.

Esfandani-Bozchaloyi, S., Sheidai, M., Keshavarzi, M. and Noormohammadi, Z. 2018b. Species Identification and Population Structure Analysis In Geranium Subg. Geranium (Geraniaceae) . Hacquetia, 17: 235-246

Esfandani-Bozchaloyi, S., Sheidai, M., Keshavarzi, M. and Noormohammadi, Z. 2018c. Morphometric and ISSR-analysis of local populations of Geranium molle L. from the southern coast of the Caspian Sea. Cytology and genetics, 52: 309-321.

Esfandani -Bozchaloyi S and Sheidai M. 2018. Molecular diversity and genetic relationships among Geranium pusillum and G. pyrenaicum with inter simple sequence repeat (ISSR) regions, Caryologia, 71: $1-14$.

Falush, D. and Stephens, J.K. 2007. Inference of population structure using multilocus genotype data: dominant markers and null alleles. Mol. Ecol. Notes.7:574-578.

Freeland, J.R., H. Kirk and Peterson, S.D. 2011. Molecular Ecology, 2nd Ed. Wiley-Blackwell, Chichester, 464 pp.

Federov, A.A. 1974. Chromosome numbers of flowering plants. Reprint by Otto Koeltz Science Pubs. Koenigstein, Germany. 33: 926-936.

Federov, A.N.A. 1969. Chromosome numbers of flowering plants. Leningrad. 11: 927-934

Goldblatt, P. 1981. Index to plant chromosome numbers, 1975-1978. Missouri Botanical Garden Monographs in systematic Botany. 5: 543-553.

Hammer, Ø., Harper, D. and Ryan, P.D. 2012. PAST: Paleontological Statistics software package for education and data analysis. Palaeontologia Electronica. 4: 1-9.

Haragan, P.D. 1991. Weeds of Kentucky and adjacent states: A field guide. The University Press of Kentucky. Lexington, Kentucky, 44: 278-282.

Hedrick, P.W. 2005. A standardized genetic differentiation measure. Evolution 59:1633-1638.

Huson, D.H. and Bryant, D. 2006. Application of Phylogenetic Networks in Evolutionary Studies. Mol. Biol. Evol. 23: 254-267.

Hutchison, D.W. and Templeton, A.R. 1999. Correlation of pairwise genetic and geographic distance measures: inferring the relative influences of gene flow and drift on the distribution of genetic variability. Evolution 53:1898-1914.

Jolivet, C. and Bernasconi, G. 2007. Within/between population crosses reveal genetic basis for pollen competitive ability in Silenelatifolia (Caryophyllaceae). J. Evol. Biol. 20: 1361-1374.

Jost, L. 2008. GST and its relatives do not measure differentiation. Mol. Ecol. 17: 4015-4026. 
Keshavarzi, M. and Esfandani-Bozchaloyi, S. 2014a Leaf and Stem Comparative Anatomical Analysis of Three Genera of Alsinoideae (Caryophyllaceae), Iran. J. Bot. 20(1): 71-79.

Keshavarzi, M. and Esfandani-Bozchaloyi, S. 2014b. Chromosome Numbers for Some Stellaria L. (Caryophyllaceae) Species and Related Taxa Iran, Iran. J. Bot. 20(1): 36-40.

Lu, D.Q. and Rabeler, R.K. 2001.Myosoton. In: Wu, Z.Y. \& Raven, P.H. (Eds.) Flora of China, vol. 6. Science Press, Beijing; Missouri Botanical Garden Press, St. Louis, 31: 38-44

Meirmans, P.G. and Van Tienderen, P.H. 2004. GENOTYPE and GENODIVE: two programs for the analysis of genetic diversity of asexual organisms. Mol. Ecol. Notes. 4: 792-794.

Meirmans P.G. 2012. AMOVA-based clustering of population genetic data. J. Heredity. 103: 744-750.

Medrano, M. and Herrera, C.M. 2008. Geographical structuring of genetic diversity across the whole distribution range of Narcissus longispathus, a habitat-specialist, Mediterranean narrowendemic. Annal. Bot. 102: 183-194.

Moore, R.J. 1973. Index to plant chromosome numbers 1967-19'7 1. Utrecht, Netherlands, International Bureau for Plant Taxonomy and Nomenclature. 12: 539-540

Morton, J.K. 2005. Stellaria L. In: Flora of North America Editorial Committee (Eds.) Flora of North America North of Mexico, vol 5. Oxford University Press, New York, 55: 96-114.

Peakall, R. and Smouse, P.E. 2006. GENALEX 6: genetic analysis in Excel. Population genetic software for teaching and research. Mol. Ecol. Notes. 6: 288-295.

Podani, J. 2000. Introduction to the Exploration of Multivariate Data. Backhuyes, Leiden, 407 pp.

Pritchard, J.K; Stephens, M. and Donnelly, P. 2000. Inference of population structure using multilocus enotype Data. Genetics. 155: 945-959.

Rechinger, K.H. 1988. StellariaL. In Rechinger, K. H. (ed), Flora Iranica no. 163: 60- 76. Akad. Druckund Verlagsanstalt.

Runemark, H. 1996. Mediterranean chromosome number reports 6 (590-678). Flora Mediterranea 6: 223 243.

Rani, N., Vasudeva, N. and Kumar, S.S. 2012. Pharmacognostical and quality control parameters of Stellaria media Linn. -Asian Pacific Journal of Tropical Disease 22: 84-S86

Scholte, G.A.M. 1978. Biosystematic studies in the collective species Stellaria media (L.) Vill. I. Proceedings of the KoninklijkeNederlandseAkademie van Wetenschappen C 81: 442-456.

Slatkin, M. 1993. Isolation by distance in equilibrium and non-equilibrium populations. Evolution. 47: $264-$ 279.

Slavokhotova, A.A, Odintsova, T.I. and Rogozhin, E.A. 2011. Isolation, molecular cloning and antimicrobial activity of novel defensins from common chickweed (Stellaria media L.) seeds. Biochimie. 93:450-56.

Ullah, F., Nasar, S. and Zaman, W. 2019. Using palynomorphological characteristics for the identification of species of Alsinoideae (Caryophyllaceae): a systematic approach. Grana 58: 174-184.

Ullah, F, Shah, S.N., Zaman, W and Ali, C. 2018. Traditional knowledge of medicinal herbs among indigenous communities in Maidan Valley, Lower Dir, Pakistan. Bull Env Pharmacol Life Sci 7: 11-23.

Verkleij, J.A.C. de Boer, A.M. and Lugtenborg, T.F. 1980. On the Eeogeneties of Stellaria media (L.) Viii. and Stellaria pallida (Dnm.) Pire from Abandoned Arable Field. Oecologia (Berl.) 46: 354-359.

Weising, K., Nybom, H., Wolff, K. and Kahl, G. 2005. DNA Fingerprinting in Plants. Principles, Methods, and Applications. 2nd ed. CRC Press, Boca Rayton, 22: 472-481. 